\title{
Analysis of the spatial variability in abundance and age structure of two infaunal bivalves, Cerastoderma edule and C. lamarcki, using hierarchical sampling programs
}

\author{
Mats Lindegarth $^{1}$, Carl André ${ }^{1,2}$, Per R. Jonsson ${ }^{1}$ \\ ${ }^{1}$ Tjärnö Marine Biological Laboratory, S-452 96 Strömstad, Sweden \\ ${ }^{2}$ Department of Zoology, Stockholm University, S-106 91 Stockholm, Sweden
}

\begin{abstract}
Spatial variability in abundance and age distribution of 2 infaunal bivalves, Cerastoderma edule (Linnaeus, 1785) and C. lamarcki (Reeve, 1845), were quantified using hierarchical sampling programs. The scales investigated ranged between $10^{\circ}$ and $10^{5} \mathrm{~m}$. Analyses of variance revealed significant variability in abundance among sites within bays $(\sim 100 \mathrm{~m}$ apart $)$ for both species and also among bays ( $1 \mathrm{~km}$ apart) for C. lamarcki. Mean age varied at several spatial scales. For both species, however, the scale contributing most to the variation was bays, which provided about $40 \%$ of the total variation for each species. Randomization procedures were used to test the generality of previous observations of non-random distributions of year classes (namely number of year classes and dominance by single year classes). These analyses showed that for both species a spatial unit contained significantly fewer year classes and the most abundant year class was significantly more abundant than expected by chance. These results were consistent for all spatial scales except among plots $\left(\sim 10^{1} \mathrm{~m}\right.$ apart) in C. lamarcki. The necessity to assess spatial patterns at a wide range of spatial scales is emphasized. Potentially important processes (focusing on larval supply and recruitment) which generate the observed patterns and general implications of spatial variability are discussed.
\end{abstract}

KEY WORDS: Cerastoderma $\cdot$ Spatial variation $\cdot$ Hierarchical sampling $\cdot$ ANOVA $\cdot$ Randomization tests

\section{INTRODUCTION}

Spatial variability is a fundamental characteristic of animal and plant populations and community structure, as well as of the environment which the organisms inhabit. Observation of spatial or temporal variability of some variable (e.g. abundance of an organism) is often the starting point from which questions and hypotheses about important processes on the individual, population or community level are generated (Levin 1992). Spatial variability may have major functional consequences to processes acting on different levels of organisation. Processes, such as reproduction, competition and predation, may be severely affected by the spatial distribution of individuals in a population or a community and consequently many authors have urged the incorporation of spatial heterogeneity into population and community models
(Kareiva 1990, Hanski 1991). The potentially extensive ecological consequences of spatial heterogeneity and the fact that models and hypotheses, e.g. about the distribution of some organism, are based on observations emphasise the need for objective and general field observations (Underwood 1991). It is important to clarify the fundamental, logic distinction between the objectives of observational studies and controlled experiments. The former can only be used to detect patterns of variability, whilst the latter have the potential of evaluating hypotheses about specific mechanisms (Underwood \& Denley 1984, Underwood 1985). Nevertheless, general observations of patterns in nature play a crucial role in defining relevant questions and evaluating predictions from general models.

Following Pielou (1977), many authors distinguish between 2 features of spatial patterns: intensity and grain. Intensity represents the relative difference be- 
tween areas of high and low density. Grain is the size and arrangement of areas of high density. A description of spatial pattern is, however, always connected to a certain, clearly specified, spatial level and is not necessarily relevant to other spatial scales. This makes the characterization of spatial patterns more complicated (Hurlbert 1990, Kotliar \& Wiens 1990), and the necessity to assess spatial patterns at multiple spatial scales becomes evident (Levin 1992). In descriptions of observed patterns, the heterogeneity can be evaluated either at a continuous scale (e.g. autocorrelation techniques), or within a hierarchical framework (e.g. nested analysis of variance). In benthic, soft-bottom ecology, serial data and spatial autocorrelation techniques have been used to define the patch structure within a specified area (e.g. McArdle \& Blackwell 1989, Thrush et al. 1989). Others have adopted the approach of hierarchi$\mathrm{cal}$ analyses of variance, using either a regular (Green \& Hobson 1970) or a randomized sampling design (Morrisey et al. 1992).

In this study the spatial variability in abundance and age structure of Cerastoderma edule (Linnaeus, 1785) and C. lamarcki (Reeve, 1845) are investigated [C. lamarcki was formerly referred to as C. glaucum in northern European waters; e.g. Boyden (1971) but see Brock (1987)]. Both species are conspicuous infaunal components of littoral, muddy-sandy bottoms along the Swedish west coast, in addition to most of the European Atlantic coast (Brock 1979). The 2 species may be found sympatrically, although it is often held that the core habitats differ between the 2 species with regard to salinity, sediment characteristics and temperature (Boyden \& Russel 1972, Barnes 1973, Brock 1991).

The limited mobility of adult Cerastoderma edule and $C$. lamarcki suggests that processes involved in the recruitment of new individuals play a central role in generating spatial patterns of abundance. Recruitment involves the supply of larvae, settlement and survival of juveniles. Both species have free-spawning, external fertilization and planktivorous larvae. After a planktonic phase of 2 to $4 \mathrm{wk}$ (Creek 1960, Kingston 1974) the larvae settle at a size of 250 to $350 \mu \mathrm{m}$ during June and July. Several studies indicate that within a certain area, recruitment in $C$. edule may be highly variable on a year to year basis (e.g. Hancock \& Urquhart 1965, Beukema 1982, Möller \& Rosenberg 1983, Jensen 1992), but less is known regarding spatial variability in recruitment. In $C$. edule, earlier studies on recruitment (e.g. Baggerman 1953, Kristensen 1957, Hancock 1973, André \& Rosenberg 1991) have emphasized the importance of predation from established populations of adult conspecifics. Furthermore, for this species, several studies indicate that exceptionally cold winters may cause severe mortality of adults with a subsequent strong recruitment in the following year
(Kristensen 1957, Hancock \& Urquhart 1965, Beukema 1979, Jensen 1992). In accordance with these observations, many authors (e.g. Boyden 1972, Evans \& Tallmark 1976, Brock 1979) have noted that populations of C. edule are mainly composed of 1 or 2 dominant year classes.

Thus, there is evidence, mainly from tidal areas, of temporal and spatial patterns in abundance and age structure in Cerastoderma edule and to some extent in C. lamarcki. In this study we attempt to investigate the generality of spatial patterns of abundance and age structure with reference to different localities and spatial scales. This is done by replicated sampling and a more rigorous definition of spatial scales than previously demonstrated. The analyses mainly consist of hierarchical analyses of variance and cover scales of $10^{0} \mathrm{~m}$ to $10^{5} \mathrm{~m}$. Furthermore, information about spatial variability provides an important background for the objectives and design of future studies, with tests of specific hypotheses about the population dynamics and distribution of $C$. edule and C. lamarcki.

\section{MATERIALS AND METHODS}

General sampling design. The area covered in this study, the northern parts of the Swedish west coast, is a marginal part of the North Sea (Fig. 1). The area is influenced by several water masses and coastal currents with varying salinity and is practically atidal (tidal range $0.3 \mathrm{~m}$ ). However, in response to changes in air pressure and winds, the sea level may fluctuate by up to $2 \mathrm{~m}$ (Johannesson 1989). The geomorphology mostly consists of rocky shores, frequently interrupted by shallow, soft-bottom bays and fjords (length generally on the order of $10^{2}$ to $10^{3} \mathrm{~m}$ ).

Analysis of spatial patterns was done by hierarchical analysis of variance (ANOVA) (Underwood 1981, Montgomery 1991). In contrast to spatial autocorrelation analysis, this technique has the potential for a unified analysis of a very wide range of spatial scales (in this study $10^{0}$ to $10^{5} \mathrm{~m}$ ). The objective was to identify the scales that contributed most to the variation in abundance and age (Morrisey et al. 1992). This can be achieved with a completely hierarchical sampling design, in which different spatial scales are considered as random factors. The $F$-test for each factor then becomes a test of whether each spatial level contributes significantly to the observed total variation. From the mean square estimates, ANOVA further allows a quantitative measure of the variation associated with each factor in the analysis (Montgomery 1991). Two separate sampling programmes were designed for the investigations of abundance and agestructure respectively. 
Fig. 1. Map sampling design for the investigations of spatial variability in abundance (a to i) and age structure $(\mathrm{j}$ to $\mathrm{m}$ : Cerastoderma edule; $\mathrm{n}$ to $\mathrm{q}: \mathrm{C}$. lamarcki). Bays: (a) Likholmen; (b) Brevik; (c) Bålerödsviken; (d) Dannholmen; (e) Jorefjorden; (f) Långesjö; (g) Stensjö; (h) Kvarnvik; (i) Tryggöskär; (j) Nyckelbyviken; (k) Hasslebukten; (I) Edsviken; (m) Kämpersvik; (n) Havstenssund; (o) Galtöleran; (p) Dillehuvud; (q) Daftöleran

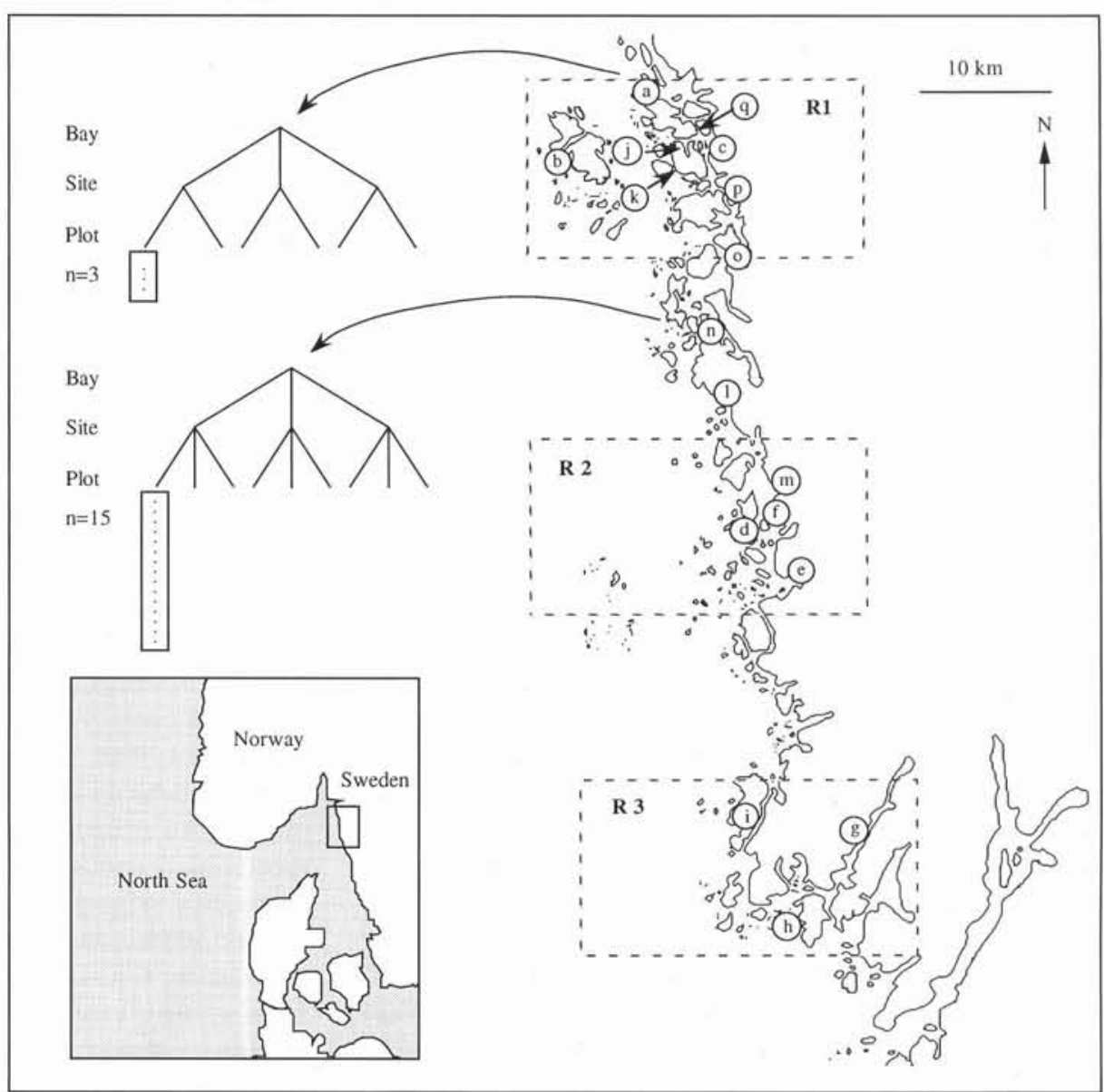

Analysis of variability in abundance. The abundances of adult Cerastoderma edule and C. lamarcki were investigated along a $70 \mathrm{~km}$ section of the Swedish west coast (Fig. 1) between July 7 and 23, 1992. A sampling program was designed by selecting: 3 regions (R); 3 bays (B) within each region (Fig. 1, Bays a to i); 3 sites (S) within each bay; 2 plots (P) within each site; and within each plot 3 replicate cores. This makes a total of 162 samples to detect variability at scales ranging from $10^{5}$ to $10^{\circ} \mathrm{m}$ (Table 1 ). The estimates of abundance for C. edule and C. lamarcki were obtained from the same cores and each species was considered in separate analyses. The linear model for each analysis was:

$$
\begin{aligned}
X_{\mathrm{ijklm}} & =\mu+\mathrm{R}_{i}+\mathrm{B}(\mathrm{R})_{j(i)}+\mathrm{S}(\mathrm{B}(\mathrm{R}))_{k(j(i))} \\
& +\mathrm{P}(\mathrm{S}(\mathrm{B}(\mathrm{R})))_{l(k(j(i)))}+\varepsilon_{i j k l m}
\end{aligned}
$$

where $X$ is abundance, $\mu$ is the overall mean, $\mathrm{R}_{i}$ is the effect of the $i$ th region, $B(R)_{j(i)}$ is the effect of the $j$ th bay, $\mathrm{S}(\mathrm{B}(\mathrm{R}))_{k(j i(i))}$ is the effect of the $k$ th site, $\mathrm{P}(\mathrm{S}(\mathrm{B}(\mathrm{R})))_{l(k(j i(i)))}$ is the effect of the 1 th plot, and $\varepsilon_{i j k l m}$ is the error term.

Sampling was performed with a corer $(\varnothing=0.31 \mathrm{~m}$, height $=0.10 \mathrm{~m}$ ), which was pushed into the sediment and dug out. No information on the small-scale spatial variability was available beforehand for the 2 species. The rationale for using this size of sampling unit was practical, but the chosen core size is approximately 40 times larger than the area occupied by large cockles. This is well above the minimum recommendation (20 times) given by Green (1979). The consequences of

Table 1. Approximate hierarchical, spatial scales, for which variability in abundance and age structure was investigated in Cerastoderma edule and C. larmarcki on the Swedish west coast

\begin{tabular}{|lcc|}
\hline Source of variation & Levels & Scale $(\mathrm{m})$ \\
\hline Abundance & & \\
Region, R & 3 & $10^{4}$ to $10^{5}$ \\
Bay, B(R) & 3 & $10^{3}$ to $10^{4}$ \\
Site, S(B, R) & 3 & $10^{2}$ \\
Plot, P(S, B, R) & 2 & $10^{1}$ \\
Replicate, residual & 3 & $10^{0}$ \\
Age structure & & \\
Bay, B & 4 & $10^{3}$ to $10^{4}$ \\
Site, S(B) & 3 & $10^{2}$ \\
Plot, P(S, B) & 3 & $10^{1}$ \\
Replicate, residual & 15 & $<3 \times 10^{0}$ \\
\hline
\end{tabular}


size of the corer and the number of replicates will be discussed below. The cockles were immediately extracted from the sediment with a $2 \mathrm{~mm}$ mesh sieve, thus the investigation of abundances does not include newly settled juveniles and larvae $(<2 \mathrm{~mm})$.

The bays within each region were selected using random numbers, which served as co-ordinates in a map of the area. A few restrictions to the random selection of the bays were applied: (1) sampling was carried out within the 0 to $1 \mathrm{~m}$ isobath (cockles are seldom observed below $2 \mathrm{~m}$ in the area; pers. obs.); (2) bottoms with gravel and rocky bottoms were excluded; and (3) the bay should be big enough to allow balanced sampling (>150 m long). The logical effect of posing restrictions to random sampling is that the hypotheses tested become less general and extrapolation of the results to other situations (e.g. smaller bays) requires that there is no bias in density of cockles due to the sizes of bays.

Analysis of variability in age. The age structure of Cerastoderma edule and C. lamarcki was determined from samples collected in 1992 during August 28 to October 16 and October 1 to 27 , respectively. The rationale for these observations was mainly to supplement the investigation of abundances with information which contained temporal components of recruitment and survival.

Bays sampled for the investigation of age structures were randomly selected from a set of bays in the northern part of the study area, known to contain either of the 2 species. Only 1 species was collected from each bay. Differences in age structure among species could be evaluated using the nested factor of bays within species. To achieve a balanced design, a $3 \times 3 \mathrm{~m}$ bottom area was subsampled with a bailer. The sediment was immediately sieved with a $2 \mathrm{~mm}$ mesh until at least 15 individuals were collected and age determined as described below. For each species (Sp), replicated sampling was performed at 4 spatial scales: 4 bays (Fig. 1: Cerastoderma edule Bays $\mathrm{j}$ to $\mathrm{m}$, C. lamarcki Bays $\mathrm{n}$ to q); 3 sites within each bay; 3 plots within each site; and within each plot 15 replicate individuals were sampled (Table 1). Thus for each species, a total of 540 individuals were measured and age determined and the linear model was:

$$
\begin{aligned}
X_{i j k l m} & =\mu+\mathrm{Sp}_{i}+\mathrm{B}(\mathrm{Sp})_{j(i)}+\mathrm{S}(\mathrm{B}(\mathrm{Sp}))_{k j(i(i))} \\
& +\mathrm{P}(\mathrm{S}(\mathrm{B}(\mathrm{Sp})))_{l(k j(i j))\}}+\varepsilon_{i j k l m}
\end{aligned}
$$

where $X$ is age, $\mu$ is the overall mean, $\mathrm{Sp}_{i}$ is the effect of the $i$ th species, $\mathrm{B}(\mathrm{Sp})_{j(i)}$ is the effect of the $j$ th bay, $\mathrm{S}(\mathrm{B}(\mathrm{Sp}))_{k(i(i))}$ is the effect of the $k$ th site, $\mathrm{P}(\mathrm{S}(\mathrm{B}(\mathrm{Sp})))_{(k(k j(i)))}$ is the effect of the $l$ th plot, and $\varepsilon_{i j k l m}$ is the error term.

To properly characterize frequency distributions (e.g. the age structures of Cerastoderma edule and C. lamarcki) a number of parameters may be employed. The ANOVA, however, only focus on dif- ferences in means and variability associated with the different spatial scales. Thus, there are several ways in which age structures may differ that are not investigated in this study. Nevertheless, rejection of the $H_{0}$ of equal mean ages among bays provides evidence that the age structures differ.

As pointed out earlier, previous studies indicate that populations of Cerastoderma edule are dominated by one or a few year classes. To test whether the number of year classes and the frequency of the most dominant year class deviated from what is expected by chance, 2 separate types of randomization tests were designed (see below). In these randomization tests, individuals were randomly allocated among the units of the particular spatial level investigated. Thus, to estimate the expected number of year classes and the frequency of the most dominant year class in a plot, individuals were randomly allocated to plots within their original site. The analogous procedures were employed among sites and bays. For the investigation of the expected number of year classes present at a particular spatial unit, the data were scored as the mean number of year classes. The data on the degree of dominance of the most frequent year class were scored as the mean frequency of the most dominant year class.

Randomization (permutation) tests. In a randomization test for significance, the test statistic resulting from the original arrangement of numbers is compared to test statistics calculated from randomly rearranged sets of data. If the original test statistic is extreme, to a level specified by $\alpha$, the original order of the data set is judged to be significantly different from random (Edgington 1986, Manly 1991). In contrast to ordinary parametric procedures, randomization methods do not rely on any parametric assumptions (Pearson 1937, Kempthorne 1955, Sokal \& Rohlf 1981). Another advantage of randomization tests is the possibility to design specific tests in non-standard situations (Edgington 1986, Manly 1991). In this study, randomization tests were employed to test whether the number of year classes and the frequency of the most abundant year class deviated from randomness at each spatial level. Furthermore, in the ANOVAs outlined above, error variances were found to be significantly heterogeneous in Cochran's test for homogeneous variances. Subsequent transformations were not successful in eliminating heterogeneity. The discrete nature of the data also suggests that the assumption of normally distributed residuals may not hold. Generally ANOVA is considered to be robust to moderate violations of the underlying assumptions, especially non-normality (Hack 1958, Underwood 1981, Manly 1991, Winer et al. 1991). Nevertheless, as a precaution we performed randomization tests on untransformed data to validate tabulated p-values in cases of significantly heterogeneous variances. In the ANOVA, ran- 
domization of the data was achieved by complete random permutations over the entire data set. The number of permutations, $\mathrm{N}$, for determining p-values for the ANOVAs was 20000 and in the tests of the number of year classes and the frequency of the most dominant year class $N$ was 1000 . Below, it will be demonstrated that, in the analyses of variance, $p$-values generated by randomization and by ordinary parametric procedures were close to identical and the results will not be separately discussed. All calculations were made using the software MATLAB ${ }^{\mathrm{TM}}$ (The Math Works, Inc., Natick, $\mathrm{MA}$ ) on Macintosh computers.

Age determination. Shells of most species of bivalves exhibit more or less pronounced external growth marks corresponding to seasonal fluctuations in the growth rate (Orton 1923, Haskin 1954). In both Cerastoderma edule and C. lamarcki, external growth rings have frequently been used as indicators of age (e.g. Orton 1926, Boyden 1972, Brown et al. 1976, Brock 1980, Jones \& Baxter 1989, Ducrotoy et al. 1991). This method was also employed in this study. Prior to the onset of the study, we analyzed growth patterns of sectioned and polished cockles, but this method yielded similar results as the simpler analysis of external growth rings. It is, however, obvious that the method has some problems, which should be taken into account in the interpretation of the results. First, there may not be a perfect correlation between the number of growth rings and the age of an individual. It has been suggested that other kinds of disturbances than seasonal variations may affect shell formation and cause similar structures (Orton 1923, Haskin 1954). In freshwater bivalves, recent results indicate that shell size may even decrease (Downing \& Downing 1993). Second, defining a distinct growth ring is to some extent a subjective process, which may cause different results between readings by the same person and, even more likely, those by different persons. These 'reader effects' are well-known phenomena and generally tend to smooth out frequency distributions, i.e. strong year classes will appear weaker and weak year classes will appear stronger than the true age distributions (Richards et al. 1992).

In our analyses, all readings were by the same person. This implies that comparisons with age distributions from other studies should be done with caution. On the other hand, this reduces the ageing error. The error caused by repeated readings by 1 person remains. To investigate the reproducibility of age readings, we performed a test where age readings were done on each of the 2 valves, from a randomly chosen subset of the collected cockles $(n=40)$. For both species, about $40 \%$ of the replicate age readings resulted in identical scores (Cerastoderma edule, $\mathrm{r}^{2}=0.75 ; C$. lamarcki, $\mathrm{r}^{2}=0.82$ ). From this analysis it is evident that biases may be introduced between different age reading occasions. For example, in $C$. edule the predicted slope was not included in the $95 \%$ confidence interval. This emphasizes the need for proper randomization, not only during sampling but also during analysis of growth rings. In our study, individuals from 1 plot in each of the 3 sites in a bay were enumerated, pooled and their ages determined. This procedure reduces the risk of reading artefacts in tests of differences among plots and among sites. As individuals from different bays were aged on different occasions, such tests will have to be more carefully considered.

\section{RESULTS}

\section{Variability in abundance}

Cerastoderma edule and C. lamarcki occurred in 8 and 6 , respectively, of the 9 randomly selected bays (Fig. 2). The mean number of adult cockles per core
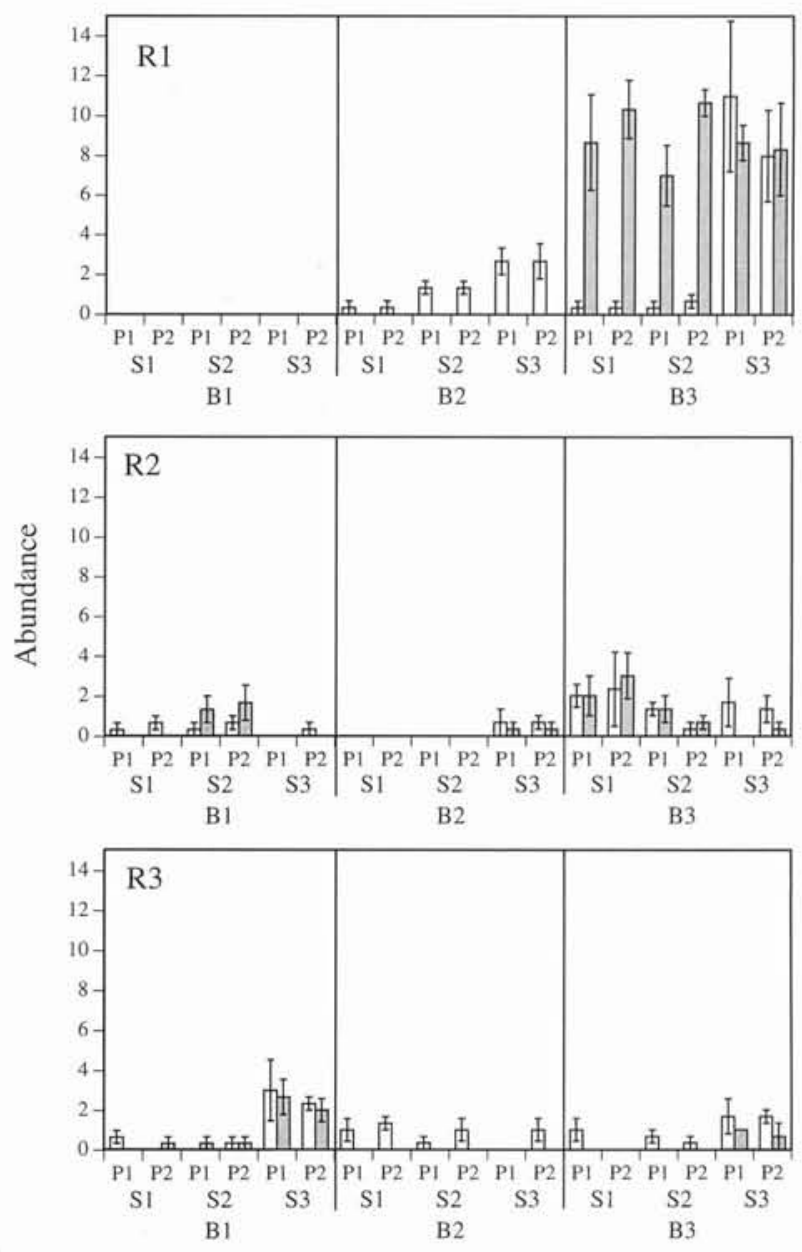

Fig. 2. Abundances (mean $\pm \mathrm{SE}, \mathrm{n}=3$ cores each) of Cerastoderma edule (open columns) and C. lamarcki (shaded columns). The order of the bays, within each region, corresponds to the order in Fig. 1. R: region; B: bay; S: site; P: plot 
Table 2. Analysis of variance in abundance of Cerastoderma edule and $C$. lamarcki. Cochran's test for homogeneous variances resulted in significant heterogeneity $(C=0.42$ for $C$. edule and $C=0.25$ for $C$. larmarcki, $\mathrm{df}=54,2)$. Tests for significance were performed parametrically and by random permutations $(\mathrm{N}=20000)$. Values in bold indicate significant effects

\begin{tabular}{|c|c|c|c|c|c|c|}
\hline Source & df & MS & F & p-value & $\begin{array}{l}\text { Randomized } \\
\text { p-value }\end{array}$ & $\begin{array}{l}\text { Variance } \\
\text { component }\end{array}$ \\
\hline \multicolumn{7}{|l|}{ C. edule } \\
\hline Region & 2 & 12.8 & 0.610 & 0.574 & 0.581 & $0^{\mathrm{a}}$ \\
\hline $\operatorname{Bay}(\mathrm{R})$ & 6 & 21.0 & 0.982 & 0.466 & 0.457 & $0^{a}$ \\
\hline Site(B, R) & 18 & 21.4 & 26.8 & 0.0001 & 0.0001 & 3.43 \\
\hline Plot(S, B, R) & 27 & 0.796 & 0.420 & 0.994 & 0.991 & $0^{a}$ \\
\hline Residual & 108 & 1.87 & & & & 1.90 \\
\hline \multicolumn{7}{|l|}{ C. lamarcki } \\
\hline Region & 2 & 111 & 0.677 & 0.543 & 0.542 & $0^{\mathrm{a}}$ \\
\hline Bay(R) & 6 & 163 & 59.3 & 0.0001 & 0.0001 & 8.92 \\
\hline Site(B, R) & 18 & 2.75 & 2.65 & 0.0107 & 0.0158 & 0.286 \\
\hline Plot(S, B, R) & 27 & 1.04 & 0.804 & 0.738 & 0.737 & $0^{\mathrm{a}}$ \\
\hline Residual & 108 & 1.29 & & & & 1.29 \\
\hline
\end{tabular}

show any significant variability at smaller scales, as plots within sites, $\sim 10 \mathrm{~m}$ apart, did not differ significantly.

Partitioning of the variance components associated with the spatially different scales adds further insight to the variability in abundance of Cerastoderma edule and C. lamarcki (Table 2). The major result when partitioning the variance components is the difference between the 2 species in the variability attributed to bays. For $C$. edule, the contribution of bays to the total variation is 0 , while in C. lamarcki the difference among bays explains $80 \%$ of the total variation. For $C$. edule, most of the variation (64\%) appears among sites within a bay. Furthermore, the residual variances for the 2 analyses gives a substantial contribution (37 and $12 \%$ respectively) to the total variation, indicating a comparatively large variation among replicate cores. In terms of precision this can be

was 0.36 for $C$. edule and 0.44 for $C$. lamarcki, yielding average densities of 1.2 and $1.5 \mathrm{~m}^{-2}$, respectively in shallow bays along the northern portion of the Swedish west coast. ANOVAs on abundance of $C$. edule and C. lamarcki revealed significant patterns at different spatial scales (Table 2). Both species appeared in all regions and the abundances did not differ significantly among regions. On the other hand, the abundances of $C$. edule and $C$. lamarcki both varied significantly among sites located $<150 \mathrm{~m}$ apart. In addition $C$. lamarcki varied significantly among bays within regions. The analyses also suggest that none of the species expressed as SE/mean ratios for each plot, which were calculated to be $0.6 \pm 0.3$ and $0.5 \pm 0.4$ (mean $\pm \mathrm{SD}$ ) for C. edule and C. lamarcki respectively.

\section{Variability in age}

Table 3 shows the results of the age analysis in Cerastoderma edule and C. lamarcki. In the analysis the sums of squares of each species are partitioned within each spatial level to allow separate F-tests within each species. No tests were performed on the

Table 3. Analysis of variance on age of Cerastoderma edule and C. lamarcki. Cochran's test for homogeneous variances resulted in significant heterogeneity $(C=0.124, \mathrm{df}=1080,14)$. Tests for significance were performed parametrically and by random permutations $(\mathrm{N}=20000)$. Values in bold indicate significant effects

\begin{tabular}{|c|c|c|c|c|c|c|c|c|}
\hline Source & Abbreviation & df & MS & F & $\begin{array}{c}F \text {-ratio } \\
\text { vs }\end{array}$ & p-value & $\begin{array}{c}\text { Randomized } \\
\text { p-value }\end{array}$ & $\begin{array}{l}\text { Variance } \\
\text { component }\end{array}$ \\
\hline Species & $\mathrm{Sp}$ & 1 & 1645 & 4.70 & MS B(Sp) & 0.0732 & 0.072 & \\
\hline Bay(Sp) & $\mathrm{B}(\mathrm{Sp})$ & 6 & 350 & & & & & \\
\hline $\mathrm{B}(\mathrm{C}$. edule $)$ & $\mathrm{B}(\mathrm{C} . \mathrm{e})$ & 3 & 280 & 15.8 & MS S(C.e) & 0.001 & 0.0014 & 1.95 \\
\hline B(C. lamarcki) & $\mathrm{B}(\mathrm{C} .1)$ & 3 & 419 & 20.1 & MS S(C.I) & 0.0004 & 0.0002 & 2.95 \\
\hline $\operatorname{Site}(B, S p)$ & $\mathrm{S}(\mathrm{B}, \mathrm{Sp})$ & 16 & 19.3 & & & & & \\
\hline $\mathrm{S}(C$. edule $)$ & P(C.e) & 8 & 17.7 & 1.13 & MS P(C.e) & 0.38 & 0.37 & 0.05 \\
\hline $\mathrm{S}(\mathrm{C}$. lamarcki $)$ & $\mathrm{P}(\mathrm{C} .1)$ & 8 & 20.8 & 3.89 & MS P(C.l) & 0.0045 & 0.0049 & 0.34 \\
\hline Plot(S, B, Sp) & $\mathrm{P}(\mathrm{S}, \mathrm{B}, \mathrm{Sp})$ & 48 & 10.5 & & & & & \\
\hline $\mathrm{S}(\mathrm{C}$. edule $)$ & $\mathrm{P}(\mathrm{C} . \mathrm{e})$ & 24 & 15.7 & 9.83 & MS R(C.e) & 0.0001 & 0.0001 & 0.94 \\
\hline S(C. lamarcki) & $\mathrm{P}(\mathrm{C} .1)$ & 24 & 5.35 & 1.55 & MS R(C.l) & 0.048 & 0.049 & 0.13 \\
\hline Residual & & 1008 & 2.53 & & & & & \\
\hline $\mathrm{R}(C$. edule $)$ & $\mathrm{R}(\mathrm{C} . \mathrm{e})$ & 504 & 1.59 & & & & & 1.59 \\
\hline $\mathrm{R}($ C. lamarcki) & $\mathrm{R}(\mathrm{C} . \mathrm{l})$ & 504 & 3.46 & & & & & 3.46 \\
\hline
\end{tabular}


spatial levels containing variation from both species [B(Sp), S(B, Sp) and P(S, B, Sp)].

The analysis of age revealed no significant difference in mean age between the 2 species. However, the power of the test was only 0.38 which means that if the measured difference of the means $(2.5 \mathrm{yr}$; noncentrality parameter, $\Phi=1.36$ ) reflects a true difference we would only identify this difference as significant with a probability of 0.38 given the present sampling design. The mean age of both species varied significantly at various spatial scales (Table 3 ). For both species the mean age varied among bays. Furthermore, there was significant variation among plots in Cerastoderma edule and in C. lamarcki, both sites and plots contributed significantly to the total variation. Fig. 3 shows that generally all year classes are represented in all bays, although reading errors may have smoothed out the distributions. For each species, the age structures in each bay are usually uni- or bimodal with the modes varying among bays. The same pattern emerges when the age structures are shown for each site separately (Fig. 4). It should be noted that Figs. $3 \& 4$ represent age structures of individuals pooled within bays and sites, which means that individuals were not randomly sampled at these spatial levels. All statistical tests are, however, done with the appropriate degrees of freedom.

\section{C. edule}

B1

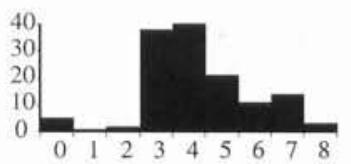

B2

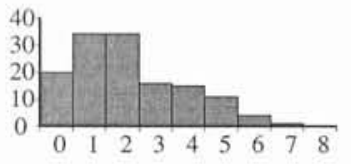

B3
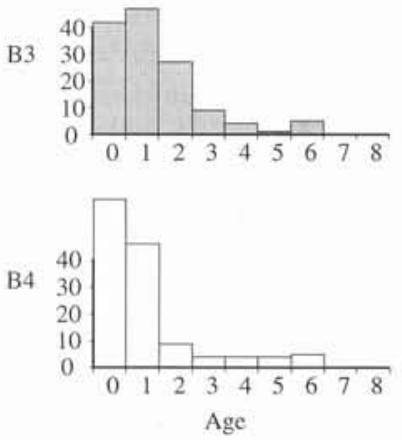

C. lamarcki
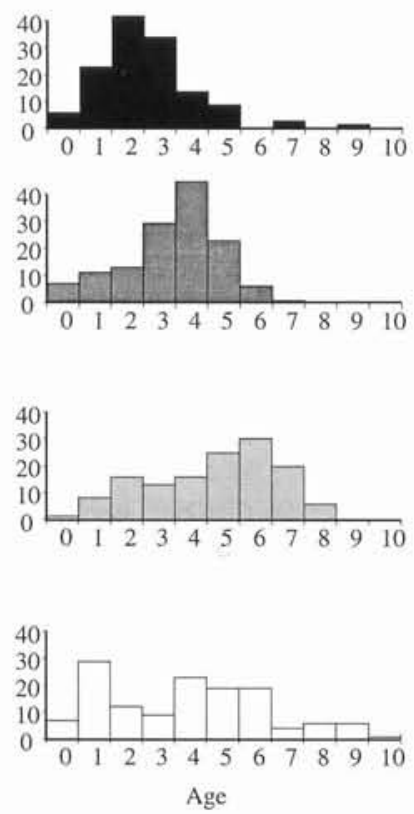

Fig. 3. Age distributions of the investigated bays containing populations of Cerastoderma edule and C. lamarcki $(n=135)$. Each bay is shaded differently. The order of the bays, within each species, corresponds to the order in Fig. 1
Partitioning of the variance components associated with each spatial scale within each species reveals that a large proportion $(43 \%)$ of the total variability in age of both Cerastoderma edule and C. lamarcki is accounted for by differences among bays (Table 3 ). The remaining variability is mainly found among individuals within plots, but, in $C$. edule, a considerable contribution $(21 \%)$ is also provided by plots within sites. In C. lamarcki, it is interesting to note that, although resulting in significant $F$-ratios, the variance components associated with sites and plots are much smaller than the contribution from bays. As described above, the sampling of different bays containing C. edule and C. lamarcki was carried out over approximately 2.5 and 1 mo respectively. This means that the test of potential differences among bays may be confounded by time. Indeed, Fig. 5 suggests that the test of differences among bays may have been affected by time for $C$. edule. The probability that the bays will be ranked in the order that they were sampled is $2 / 4 !=0.083$. The consequences of this potential effect on the analysis of age structure in $C$. edule will be discussed later.

The randomization tests for non-randomness in number of year classes and frequency of the most abundant year class are summarized in Table 4 . The general tendency in Cerastoderma edule is that in a certain area there tend to be fewer year classes (Fig. 6a) and the most abundant year class tends to have a greater frequency (Fig. 7a) than expected by random allocation of the individuals among the units of the spatial level investigated. This indicated that, at each spatial level, different year classes are present in the units over which randomization was performed. Furthermore, the most dominant year class varies among the units. In $C$. lamarcki the randomization tests indicate that the year classes are randomly distributed among plots within sites (Fig. 6b) and that the same year class dominates all plots within a site (Fig. 7b). Among sites within bays and among bays, however, the individuals are non-randomly distributed.

\section{DISCUSSION}

\section{Observations of spatial patterns of abundance}

The analysis of spatial structure of abundance of the 2 species (Table 2) may be summarized by representing the variance, estimated as the mean square, as a function of distance between sample locations (Green \& Hobson 1970). The patterns that emerge from Fig. 8 suggest that Cerastoderma edule is mainly distributed in patches at a spatial scale of sites $\left(\sim 10^{2} \mathrm{~m}\right)$. C. lamarcki shows a more complicated patch structure with 


\section{C. edule}

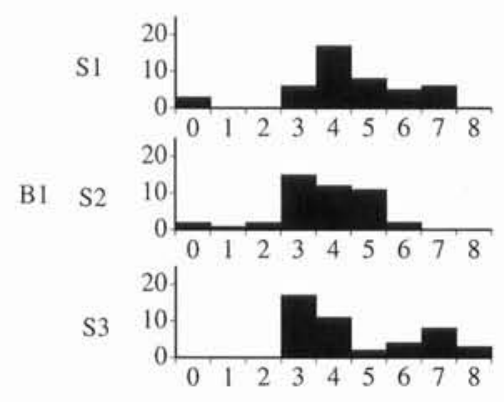

S1

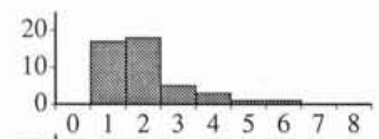

B2<smiles>[AlH2]</smiles>

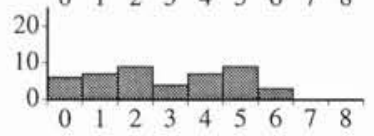

S3

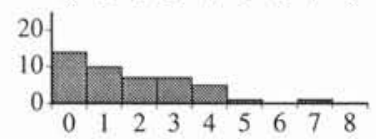

SI

B3
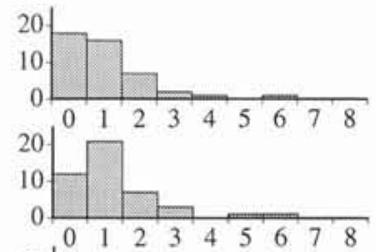

S3

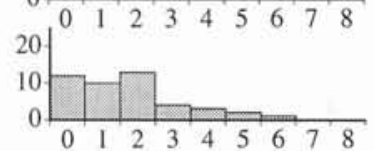

SI

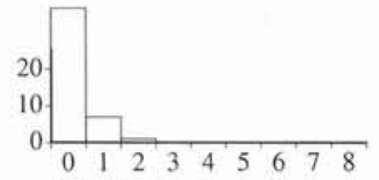

B4

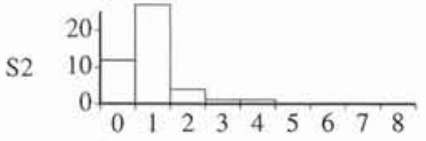

S3

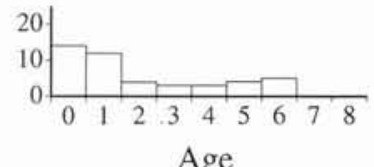

C. lamarcki
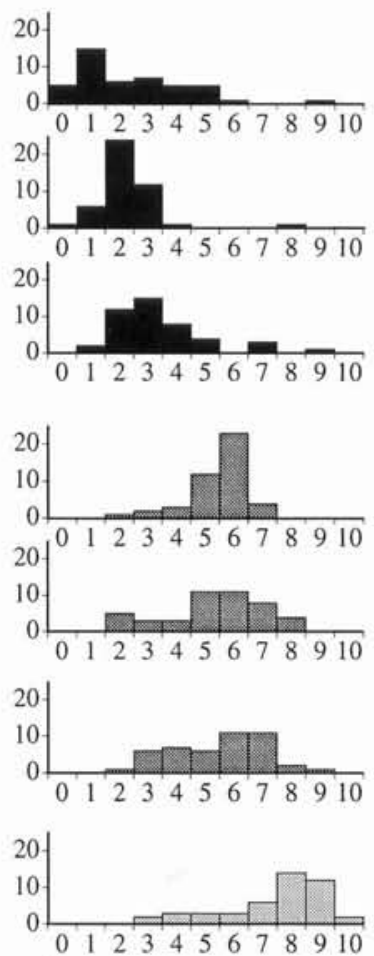

20
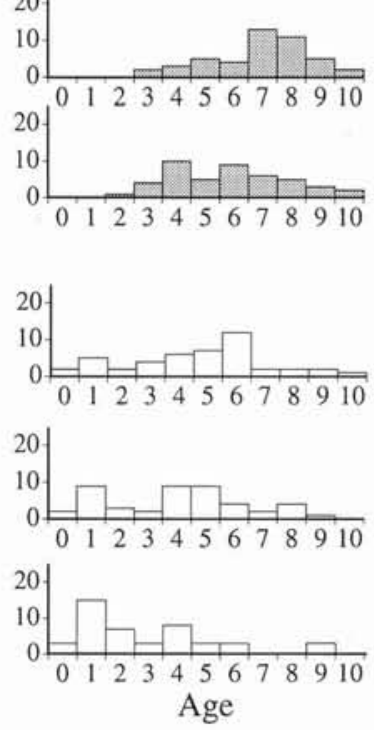

Fig. 4. Age distributions of sites within bays containing populations of Cerastoderma edule and C. lamarcki $(\mathrm{n}=45)$. Shading corresponds to shading in Fig. 3

patches at the same scale as the former species but the dominating spatial structure appears at the scale of bays $\left(\sim 10^{3}\right.$ to $\left.10^{4} \mathrm{~m}\right)$. In this study, it is only possible to evaluate patterns at scales larger than $1 \mathrm{~m}$. For both species, the variability among replicate cores provided a substantial proportion of the total variability. This suggests that patchiness at scales smaller than investi-

gated here may be present. The residual variance is also affected by the size of the sampling corer (Andrew \& Mapstone 1987). A larger corer $(0.3 \mathrm{~m}<\varnothing<1 \mathrm{~m})$ would probably have resulted in a better precision in the estimates of abundance within each plot and thus a smaller residual variance. Furthermore, the analysis of abundance yielded several negative estimates of variance components (Table 2). A negative estimate of a variance component indicates underestimation of the component of interest or overestimation of a component lower down in the analysis. (If the true value of a variance component is 0 there is a $50 \%$ chance of receiving a negative estimate.)

The proximate mechanisms causing these observed patterns of variability in abundance are presumably exceedingly diverse and complex. Most likely, the relative importance of different processes varies among spatial scales. In the following discussion of potential mechanisms, emphasis will be placed on the earliest stages of the life cycle. Due to the high reproductive output in these organisms, processes involved in the recruitment of new individuals, e.g. larval supply and settlement, have a high potential to influence the subsequent abundance and variability of adult individuals (Gaines et al. 1985, Underwood \& Fairweather 1989).

Neither of the 2 species showed any significant differences among regions. This indicates that processes acting at the scale of regions $\left(10^{4}\right.$ to $\left.10^{5} \mathrm{~m}\right)$ (e.g. differential supply of larvae associated with large-scale ocean and coastal currents) may be of minor importance in determining the abundance of the 2 species.

Given the present sampling criteria and the power of the test there was no difference in abundance of Cerastoderma edule among bays. This indicates that $C$. edule is fairly tolerant to habitat differences occurring at the scale of bays and that, at least at a temporal scale of a lifetime of $C$. edule, larvae are supplied to most bays. In C. lamarcki, however, $85 \%$ of the variability was attributed to differences in abundance among bays. A striking difference among the investigated bays was the variability in sediment characteristics. From visual inspections at each sampling site, the sediments were roughly characterized as ranging from silt to coarse sand. High densities of $C$. lamarcki were generally associated with the finer end of the sediment spectrum. 


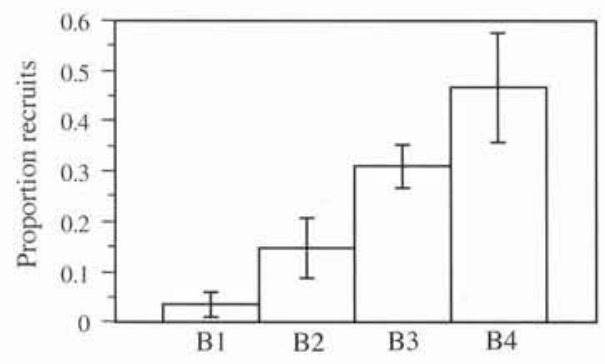

Fig. 5. Cerastoderma edule. Proportions of new recruits in bays investigated for variability in age structure in cockles (mean \pm SE). Sampling dates were August 28, September 12 , and November 1 and 16 for the for 4 bays respectively

This correlation, however, does not necessarily imply a causal relationship between sediment type and the distribution of C. lamarcki. Several models may be proposed to explain the observation of high variability in abundance among bays in C. lamarcki. Differential juvenile and/or adult mortality among bays may be responsible for the observed variability but the possibility of differential settlement, due to larval supply or habitat selection, cannot be ruled out. However, individuals of $C$. lamarcki are sometimes found in more exposed locations with sandy sediments (pers. obs.). Furthermore, the opportunities for individual larvae to exercise habitat selection at the scale of bays may be limited (Butman 1987).

In Cerastoderma edule, $64 \%$ of the variability was accounted for by differences among sites within bays. Although habitat differences among sites exist, they were less pronounced than differences among bays. On the other hand, the opportunities for habitat selection may be more important at this scale as larvae are more likely to encounter several sites within a bay. Alternative models to account for the variability among sites include local hydrodynamic processes affecting larval supply and possibly sediment transport resulting in redistribution and mortality of newly settled larvae and juveniles (Baggerman 1953, Emerson \& Grant 1991).

Table 4. Cerastoderma edule, C. lamarcki. Results of randomization tests on mean number of year classes and mean frequencies of the most abundant year class in samples at the 3 investigated spatial levels. In tests of number or year classes $H_{0}$ : original frequency $\leq$ randomized frequency. p-values were generated by 1000 random permutations within each spatial level

\begin{tabular}{|lcccc|}
\hline $\begin{array}{l}\text { Spatial } \\
\text { scale }\end{array}$ & \multicolumn{2}{c}{$\begin{array}{c}\text { No. of year classes } \\
\text { C. edule }\end{array}$} & C. lamarcki & \multicolumn{2}{c|}{$\begin{array}{c}\text { Dominance } \\
\text { C. edule }\end{array}$} & C. lamarcki \\
\hline Bay & 0.001 & 0.001 & 0.001 & 0.001 \\
Site & 0.001 & 0.012 & 0.001 & 0.001 \\
Plot & 0.001 & 0.17 & 0.001 & 0.48 \\
\hline
\end{tabular}

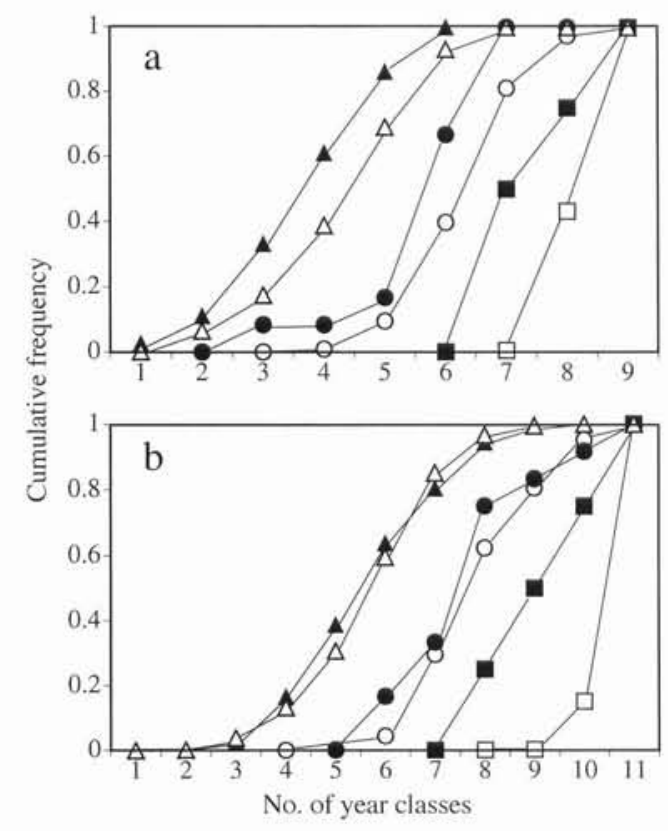

Fig. 6. (a) Cerastoderma edule, (b) C. lamarcki. Cumulative frequencies of the number of year classes present in samples from bays $(\mathbf{E}, \square)$, sites $(\bullet, 0)$ and plots $(\boldsymbol{\Lambda}, \Delta)$. Solid symbols indicate observed frequencies and open symbols indicate mean frequencies from 1000 randomizations

The present discussion intends to suggest possible processes and models to explain the observed variability in abundances of Cerastoderma edule and $C$.

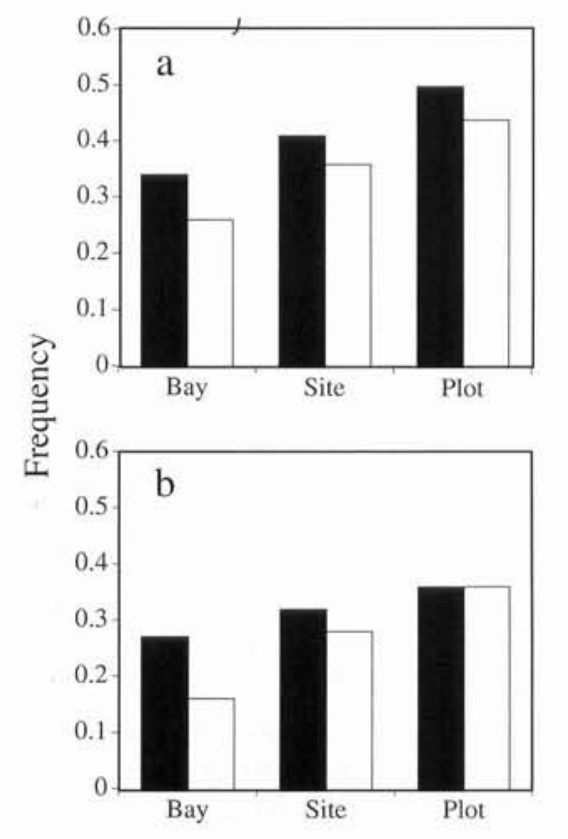

Fig. 7. (a) Cerastoderma edule, (b) C. lamarcki. Mean frequencies of the most abundant year class at each spatial level. Solid columns represent observed frequencies and open columns represent mean frequencies from 1000 randomizations 


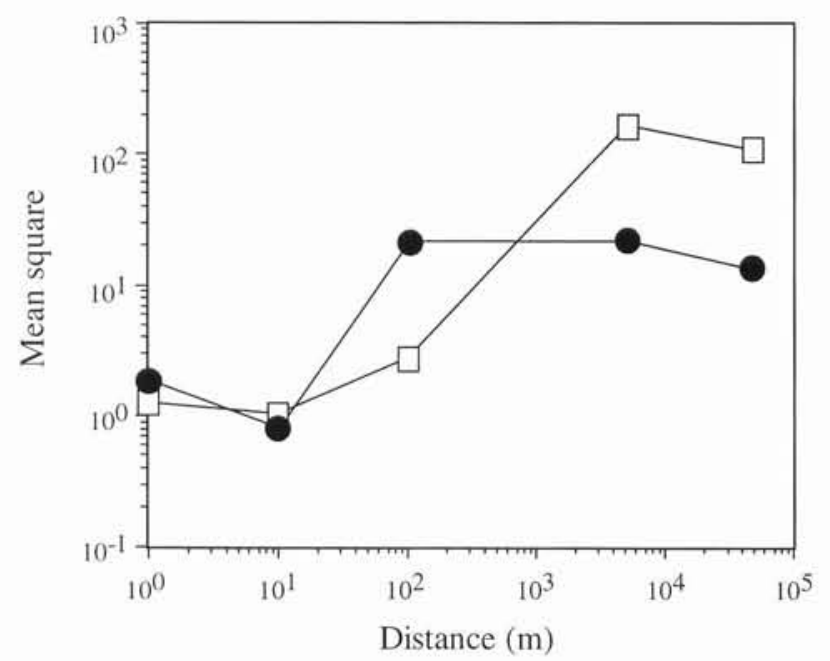

Fig. 8. Mean squares of abundances as a function of distance among sampling locations. (- Cerastoderma edule and ( $\square$ ) C. lamarcki

lamarcki. The explanatory power of these and other models remains to be tested in manipulative experiments. However, the effects of processes affecting the abundance of the 2 species are not necessarily manifested as increased variability. For example, turbulent diffusion of larvae presumably tends to homogenize the distribution of larvae. Furthermore, potentially important processes, such as competition and predation may be density dependent and tend to level out spatial variability. In this study the densities of the 2 species were generally low and competition for space or food must be considered to be minimal. Predation on larvae and juveniles, on the other hand, is very likely to be substantial. Several studies on the Swedish west coast have previously emphasized the importance of predation from fish and mobile epifauna (Pihl 1982, 1985) and adult conspecifics (André \& Rosenberg 1991, André et al. 1993).

\section{Observations of spatial variability in age}

There was no difference in mean age between Cerastoderma edule and C. lamarcki, but within each species the mean age varied at most spatial scales (Table 3 ). The low power of the test and the possibility of differences in reading errors make conclusions regarding differences among species less reliable. However, the life spans of the 2 species are apparently roughly similar and the main purpose of the observations was to investigate the spatial variability in age within each species. The results of the investigation of spatial variability in age for $C$. edule and $C$. lamarcki are summarized in Fig. 9. The general tendency is

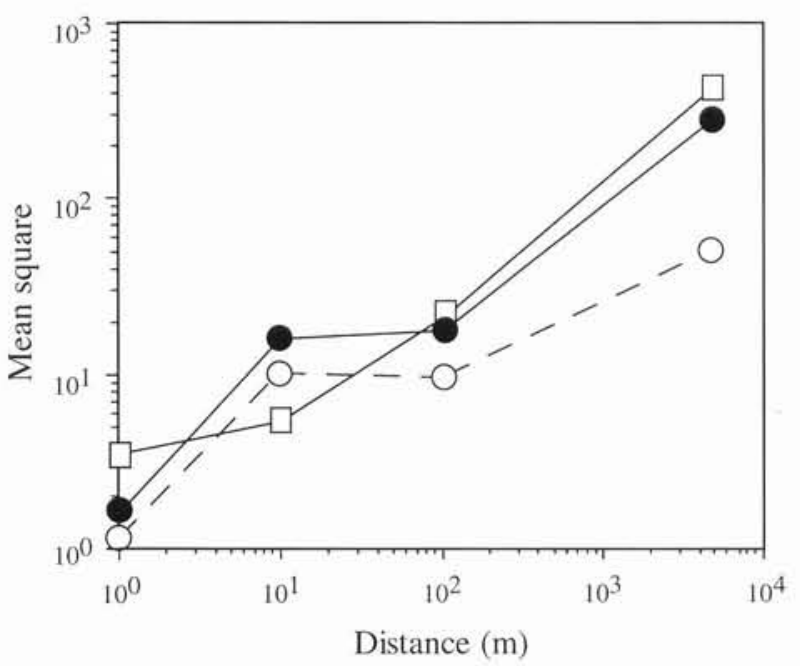

Fig. 9. Mean squares of age as a function of distance among sampling locations. (-) Cerastoderma edule, ( $\square$ ) C. lamarcki and $(\mathrm{O}) \mathrm{C}$, edule except $\mathrm{O}$-age individuals

increasing variance with increasing distance, i.e. individuals living close to each other are more likely to be of the same age than distant individuals. This indicates that there is spatial autocorrelation in recruitment and/or mortality.

For both species a major part, $43 \%$, of the total variability was caused by differences among bays ( 1 to $10 \mathrm{~km}$ scale). As previously mentioned, there is a possibility of temporal confounding in the analysis of age in Cerastoderma edule. The relatively large time span between the sampling dates of the first and last bays may have allowed an increasing number of 0 -aged individuals to grow into the detectable size class (cf. data in Möller \& Rosenberg 1983). To evaluate the sensitivity of the conclusions to this potential temporal confounding, the data on age of $C$. edule were re-analyzed after omission of new recruits and subsequent balancing of the data with respect to the number of sites and individuals. This procedure reduces the number of degrees of freedom and thus the power of the test but the results of the analysis are consistent with the analysis of the whole data set including newly recruited individuals (Table 5). From this analysis, it is not possible to conclude whether temporal confounding in the test for differences among bays actually occurred or not. The analysis shows, however, that the presence of such confounding would not severely alter the general patterns of variability (Fig. 9) and that a substantial proportion of the total variability is still provided by differences among bays.

Although significant in Cerastoderma lamarcki, the variability due to differences among sites was of minor importance for both species (Table 3). For both $C$. edule and C. lamarcki, however, a substantial propor- 
Table 5. Analysis of variance on age of Cerastoderma edule, excluding newly recruited individuals, i.e. with no growth rings $(n=7)$. Cochran's test for homogeneous variances resulted in significant heterogeneity $(C=0.186$, $\mathrm{df}=24,6)$ The effect of $\mathrm{S}(\mathrm{B})$ was highly insignificant $(\mathrm{p}>0.25)$, consequently bays could be tested against a pooled mean square of sites and plots. Tests for significance were performed parametrically and by random permutations $(N=2000)$. Values in bold indicate significant effects

\begin{tabular}{|c|c|c|c|c|c|c|}
\hline Source & df & MS & F & p-value & $\begin{array}{c}\text { Randomized } \\
\text { p-value }\end{array}$ & $\begin{array}{l}\text { Variance } \\
\text { component }\end{array}$ \\
\hline Bay & 3 & 50.1 & $\begin{array}{l}5.38 \\
5.09^{\mathrm{a}}\end{array}$ & $\begin{aligned} & 0.069 \\
<< & 0.01\end{aligned}$ & $\begin{array}{l}0.070 \\
0.009\end{array}$ & 0.97 \\
\hline Site(B) & 4 & 9.31 & 0.934 & 0.47 & 0.46 & $0^{\mathrm{b}}$ \\
\hline $\begin{array}{r}\text { Plots }(\mathrm{S}, \mathrm{B}) \\
\text { Pooled }\end{array}$ & $\begin{array}{l}16 \\
20\end{array}$ & $\begin{array}{l}9.97 \\
9.83\end{array}$ & 9.66 & 0.0001 & 0.0001 & 1.28 \\
\hline $\begin{array}{l}\text { Residual } \\
{ }^{a} F=\text { MS B } \\
{ }^{b} \text { Negative }\end{array}$ & $\begin{array}{l}144 \\
\text { SS po } \\
\text { timat }\end{array}$ & $\begin{array}{l}1.03 \\
\text { d } \\
\text { were }\end{array}$ & t to 0 & & & 1.03 \\
\hline
\end{tabular}

Furthermore, in C. edule plots tend to contain fewer year classes than expected by chance and different plots tend to be dominated by different year classes. However, in C. lamarcki individuals appear to be randomly distributed among plots. These observations could be interpreted as a result of predation from adult conspecifics in $C$. edule but conclusions about the relative importance of this mechanism as compared to other processes, e.g. settlement variability and post settlement transport (Baggerman 1953), are not justified from these data. It is, however, interesting to note that non-randomness regarding the number of year classes and dominance appears at several spatial scales and that differences exist between the 2 species.

tion, 35 and $50 \%$ respectively, of the total variability was provided by the residual variances and in $C$. edule the variability among plots within sites was relatively high $(21 \%)$.

The temporal information added by the observations of age structure provides an opportunity to further evaluate previously proposed processes affecting the spatial distribution of Cerastoderma edule and $C$. lamarcki. In the investigation of age structure a narrower sampling criterion ensured that only bays with environmental conditions suitable for either of the 2 species were sampled. Thus, it may be hypothesized that a smaller proportion of the variability results from physicochemical differences among habitats. From the analyses of age structures it is, however, evident that the age structures may be highly variable among bays for both species. The occurrence of bimodal distributions and distributions skewed to the right indicates that recruitment may be highly variable among years. Furthermore, the randomization tests revealed that, for both species, each bay contained fewer year classes than expected from random allocation of individuals among bays and that different year classes dominate in different bays. This suggests that spatially synchronized large-scale phenomena variation among years, e.g. water temperature during the summer and ice conditions during the winter (Kristensen 1957, Hancock \& Urquhart 1965, Beukema 1979), did not have a dominant effect on the age structures of $C$. edule and C. lamarcki on the Swedish west coast during the years preceding this investigation.

For both species the large variability in age within plots indicates that a wide range of year classes is expected to be present within a few meters. This implies that there are generally no marked differences in mortality among plots for either of the species.
A general conclusion that emerges from this study is that for both Cerastoderma edule and C. lamarcki spatial variability in abundance and age may be substantial at several spatial scales. Thus, any attempt to make large-scale comparisons of the population dynamics of these 2 species (e.g. Ducrotoy et al. 1991), or to use cockles for purposes of monitoring (e.g. Jones \& Baxter 1989), must take small-scale variability into account in the design of a sampling program. This may be done by completely randomized or hierarchical sampling.

Acknowledgements. This research was supported by the Swedish Natural Science Foundation through contract B-BU 06737-303 to C.A. and through contract B-BU 1860-305 to P.R.J. The foundations of Anna Ahrenberg, Colliander, Helge Ax:son Johnson and Hierta Retzius provided additional support.

\section{LITERATURE CITED}

André, C., Jonsson, P. R., Lindegarth, M. (1993). Predation on settling larvae by benthic suspension feeders: the role of hydrodynamics and larval behaviour. Mar. Ecol. Prog. Ser. 97: 183-192

André, C., Rosenberg, R. (1991). Adult-larval interactions in the suspension-feeding bivalves Cerastoderma edule (L.) and Mya arenaria L. Mar. Ecol. Prog. Ser. 71: 227-234

Andrew, N. L., Mapstone, B. D. (1987). Sampling and the description of spatial pattern in ecology. Oceanogr. mar. Biol. A. Rev. 25: 39-90

Baggerman, B. (1953). Spatfall and transport of Cardium edule L. Archs. néerl. Zool. 10: 315-342

Barnes, R. S. K. (1973). The intertidal lamellibranchs of Southampton water, with particular reference to Cerastoderma edule and C. glaucum. Proc. malac. Soc. Lond. 40: 413-433

Beukema, J. J. (1979). Biomass and species richness of the macrobenthic animals living on a tidal flat area in the 
Dutch Wadden sea: effects of a severe winter. Neth. J. Sea Res. 13: 203-223

Beukema, J. J. (1982). Annual variation in reproductive success and biomass of the major macrozoobenthic species living in a tidal flat area of the Wadden sea. Neth. J. Sea Res. $16: 37-45$

Boyden, C. R. (1971). A note on the nomenclature of two European cockles. Zool. J. Linn. Soc. 50: 307-310

Boyden, C. R. (1972). Relationship of size to age in the cockles Cerastoderma edule and C. glaucum from the river Crouch estuary, Essex. J. Conch. 27: 475-489

Boyden, C. R., Russel, P. J. (1972). The distribution and habitat range of the brackish water cockle (Cardium (Cerastoderma) glaucum) in the British Isles. J. Anim. Ecol. 40: $719-734$

Brock, V. (1979). Habitat selection of two congeneric bivalves, Cardium edule and C. glaucum in sympatric and allopatric populations. Mar. Biol. 54: 149-156

Brock, V. (1980). Evidence for niche differences in sympatric populations of Cerastoderma edule and C. lamarcki. Mar. Ecol. Prog. Ser. 2: 75-80

Brock, V. (1987). Genetic relations between the bivalves Cardium (Cerastoderma) edule, Cardium lamarcki and Cardium glaucum, studied by means of crossed immunoelectrophoresis. Mar. Biol. 93: 493-498

Brock, V. (1991). An interdisciplinary study of evolution in the cockles, Cardium (Cerastoderma) edule, C. glaucum, and C. lamarcki. Thesis, University of Copenhagen. Vestjydsk forlag, Vinderup

Brown, R. A., Seed, R., O'Connor, R. J. (1976). A comparison of relative growth in Cerastoderma (= Cardium) edule, Modiolus modiolus, and Mytilus edulis (Mollusca: Bivalvia). J. Zool. Lond. 179: 297-315

Butman, C. A. (1987). Larval settlement of soft-sediment invertebrates: the spatial scales of pattern explained by active habitat selection and the emerging role of hydrodynamical processes. Oceanogr, mar. Biol. A. Rev. 25: 113-165

Creek, G. A. (1960). The development of the lamellibranch Cardium edule L. Proc. Zool. Soc. Lond. 135: 243-260

Downing, W. L., Downing, J. A. (1993). Molluscan shell growth and loss. Nature 362: 506

Ducrotoy, J.-P., Rybarczyk, H., Souprayen, J., Bachelet, G., Beukema, J. J., Desprez, M., Dörjes, J., Essink, K., Guillou, J., Michaelis, H., Sylvand, B., Wilson, J. G., Elkaim, B., Ibanez, F. (1991). A comparison of the population dynamics of the cockle (Cerastoderma edule, L.) in north-western Europe. In: Elliott, M., Ducrotoy, J.-P. (eds.) Estuaries and coasts: spatial and temporal comparisons. Olsen \& Olsen, Fredensborg, p. 173-184

Edgington, E. S. (1986). Randomization tests. Marcel Decker, Inc., New York

Emerson, C. W., Grant, J. (1991). The control of soft-shell clam (Mya arenaria) recruitment on intertidal sandflats by bedload sediment transport. Limnol. Oceanogr. 36: 1288-1300

Evans, S., Tallmark, B. (1976). Distribution and size frequency of bivalve molluscs on a shallow, sandy bottom in Gullmar fjord (Sweden). Zoon 4: 47-52

Gaines, S., Brown, S., Roughgarden, J. (1985). Spatial variation in larval concentrations as a cause of spatial variation in settlement for the barnacle, Balanus glandula. Oecologia $67: 267-272$

Green, R. H. (1979). Sampling design and statistical methods for environmental biologists. John Wiley \& Sons, New York

Green, R. H., Hobson, K. D. (1970). Spatial and temporal structure in a temperate intertidal community, with spe- cial emphasis on Gemma gemma (Pelecypoda: Mollusca). Ecology 51: 999-1011

Hack, H. R. (1958). An empirical investigation into the distribution of the F-ratio in samples from two non-normal populations. Biometrika 45: 260-265

Hancock, D. A. (1973). The relationship between stock and recruitment in exploited invertebrates. Rapp. P.-v. Réun. Cons. Perm. int. Explor. Mer 164: 229-240

Hancock, D. A., Urquhart, A. E. (1965). The determination of natural mortality and its causes in an exploited population of cockles (Cardium edule L.). Fish. Invest. Lond. 24: 1-40

Hanski, I. (1991). Single-species metapopulation dynamics: concepts, models and observations. Biol. J. Linn. Soc. 42: $17-38$

Haskin, H. H. (1954). Age determination in molluscs. Trans. N.Y. Acad. Sci. 16: 300-304

Hurlbert, S. H. (1990). Spatial distribution of the montane unicorn. Oikos 58: 257-271

Jensen, K. T. (1992). Dynamics and growth of the cockle, Cerastoderma edule, on an intertidal mud-flat in the Danish Wadden Sea: effects of submersion time and density. Neth. J. Sea Res. 28: 335-345

Johannesson, K. (1989). The bare zone of the Swedish rocky shores: why is it there? Oikos 54: 77-86

Jones, A. M., Baxter, J. M. (1989). Monitoring and surveillance of sandy shores using the bivalve Cerastoderma edule (L.). In: McManus, J., Elliott, M. (eds.) Developments in estuarine and coastal study techniques. Olsen \& Olsen, Fredensborg, p. 63-68

Kareiva, P. (1990). Population dynamics in spatially complex environments: theory and data. Phil. Trans. R. Soc. Lond. B 330: $175-190$

Kempthorne, O. (1955). The randomization theory of statistical inference. J. Am. Stat. Ass. 50: 946-967

Kingston, P. (1974). Some observations on the effects of temperature and salinity upon the growth of Cardium edule and Cardium glaucum larvae in the laboratory. J. mar. biol. Ass. U.K. 54: 309-317

Kotliar, N. B., Wiens, J. A. (1990). Multiple scales of patchiness and patch structure: a hierarchical framework for the study of heterogeneity. Oikos 59: 253-260

Kristensen, I. (1957). Differences in density and growth in a cockle population in the Dutch Wadden Sea. Archs néerl. Zool. 12: 351-453

Levin, S. A. (1992). The problem of pattern and scale in ecology. Ecology 73: 1943-1967

Manly, B. F. (1991). Randomization and Monte Carlo methods in biology. Chapman and Hall, London

McArdle, B. H., Blackwell, R. G. (1989). Measurement of density variability in the bivalve Chione stutchburyi using spatial autocorrelation. Mar. Ecol. Prog. Ser. 52: 245-252

Möller, P., Rosenberg, R. (1983). Recruitment, abundance and production of Mya arenaria and Cardium edule in marine shallow waters, western Sweden. Ophelia 22: 33-55

Montgomery, D. C. (1991). Design and analysis of experiments. John Wiley \& Sons, New York

Morrisey, D. J., Howitt, L., Underwood, A. J., Stark, J. S. (1992). Spatial variation in soft-sediment benthos. Mar. Ecol. Prog. Ser. 81: 197-204

Orton, J. H. (1923). On the significance of 'rings' on the shells of Cardium and other molluscs. Nature 112: 10

Orton, J. H. (1926). On the rate of growth of Cardium edule. Part I. Experimental observations. J. mar. biol. Ass. U.K. 14: $239-279$

Pearson, E. S. (1937). Some aspects of the problem of randomization. Biometrika 29: 53-64 
Pielou, E. C. (1977). Mathematical ecology. John Wiley \& Sons, New York

Pihl, L. (1982). Food intake of young cod and flounder in a shallow bay on the Swedish west coast. Neth. J. Sea Res. 15: $419-432$

Pihl, L. (1985). Food selection and consumption of mobile epibenthic fauna in shallow marine areas. Mar. Ecol. Prog. Ser. 22: 169-179

Richards, L. J., Schnute, J. T., Kronlund, A. R., Beamish, R. J. (1992). Statistical models for the analysis of ageing error. Can. J. Fish. Aquat. Sci. 49: 1801-1815

Sokal, R. R., Rohlf, F. J. (1981). Biometry. Freeman and Co., New York

Thrush, S. F., Hewitt, J. E., Pridmore, R. D. (1989). Patterns in the spatial arrangements of polychaetes and bivalves in intertidal sandflats. Mar. Biol. 102: 529-535

Underwood, A. J. (1981). Techniques of analysis of variance in experimental marine biology and ecology. Oceanogr. mar. Biol. A. Rev. 19: 513-605

Underwood, A. J. (1985). Physical factors and biological

This article was submitted to the editor interactions: the necessity and nature of ecological experiments. In: Moore, P. G., Seed, R. (eds.) The ecology of rocky coasts. Hodder and Stoughton, London, p. $372-390$

Underwood, A. J. (1991). The logic of ecological experiments: a case history from studies of the distribution of macroalgae on rocky intertidal shores. J. mar, biol. Ass. U.K. 71: 841-866

Underwood, A. J., Denley, E. J. (1984). Paradigms, explanations and generalizations in models for the structure of intertidal communities on rocky shores. In: Strong, D. et al. (eds.) Ecological communities: conceptual issues and the evidence. Princeton University Press, Princeton, p. $151-180$

Underwood, A. J., Fairweather, P. G. (1989). Supply-side ecology and benthic marine assemblages. Trends. Ecol. Evol. 4: 16-20

Winer, B. J., Brown, D. R., Michels, K. M. (1991). Statistical principles in experimental design. McGraw-Hill, Inc, New York

Manuscript first received: April 25, 1994

Revised version accepted: September 29, 1994 